\title{
Mediterranean Journal of Social Sciences
}

\author{
journal homepage: www.mcser.org
}

DOI: $10.5901 /$ mjss.2011.v2n3p346

ISSN 2039-2117

\section{Hafez's and Molavi's Ideas on Meaning}

\author{
Saeed Saghe’i \\ Hamedan University of Applied Science and Technology, Iran \\ Lecturer of Public Relations, Journalism, and Management of Cultural Affairs \\ Email:Saeedsagbei@yaboo.com Phone Number: +989189066241
}

\begin{abstract}
Molavi (=Rumi) and Hafez, two Iranian poets in two succeeding centuries, have each their own ideas on meaning. Molavi uses tales with human or animal characters in a symbolic and multi-layered fashion and Hafez makes use of the natural element of Saba Wind as a channel for transferring a pleasant scent between the lover and beloved, and, thus, in this way they both confirm theories of meaning in the communication process. Case studies of Hafez's and Molavi's poetry showed that they, not unlike contemporary western thinkers such as David Berlo and Dean Barnlund, believe that communication is the process of transfer of the message from sender to receiver providing the meaning received by the receiver be similar to that intended by the sender. This aim became possible through comparing Berlo's famous communication model with Hafez's and Molavi's poems. The results will be presented in tables and diagrams and, finally, an answer will be attempted to the question as to whether it is possible to find a connection between prevailing western theories in this field and the points mentioned by Hafez and Molavi.
\end{abstract}

Keywords: Hafez' and Molavi's poetry, communication process, meaning.

\section{Introduction}

Communication Studies and its branches are relatively young disciplines, not least in Iran where media have still little experience and have not been enjoying a firm footing. But, in this very short time, in the western world, and especially in the United States, much progress has been made towards a more thorough understating of media and some considerably influential studies have been conducted. Conversely, the wide gap felt in Iran concerning such activities seems disappointing. Indeed, Iranians have been more translating the western achievements than producing their own theories.

However, if we Iranians try to develop a keen eye and take a close look at our past, we will see that we are not as unequipped as believed and we may even be able to claim a position for ourselves in the field. This will be realised only when we investigate our past works, while having a comprehensive knowledge of western theories, and try to indigenise the discipline in our own cultural and historical context.

In Iran, Dr. Kazem Mo'tamed-nezhad, who deserves to be called the father of Communication Studies in Iran, followed by Dr. Mahdi Mohseniyan-rad and Dr. Ali-Akbar Farhangi, as well as other researchers and students have taken such major steps in the field that one can claim that the process of indigenisation has already begun since years ago and is progressing ahead. However, since the scientific, cultural and literary works of the past are extremely immense and profound and, despite the intensive work of generations of researchers, many of their dimensions are still unknown to us, an urgent need is felt to decode these scholarly and sophisticated works. Mohseniyan-rad, through his Cultural Roots of Communication in Iran and Iran in Four Communication Galaxies, and Farhangi, through numerous books and particularly Human Communication, have made their scholarly findings available to Iranian researchers. Undoubtedly, Mohseniyan's Cultural Roots of Communication in Iran is the first comprehensive work to decode the Iranian poems of previous centuries which carefully addresses numerous aspects like, for instance, proverbial expressions. But, as mentioned earlier, since there is still much room for further research, the present paper, by performing case studies on Molavi (=Rumi) and Hafez-two Iranian 
poems who enjoy a universal reputation, - seeks to briefly approach a single aspect of Communication Studies, i.e. the issue of meaning in communication, from the viewpoint of adaptation and indigenisation in order to come to a better understanding of this issue as well as to discover new aspects of mystical and knowledgeable character of these two prominent poets. This will help provide a proper answer to questions such as: How can we discover western concepts and theories of communication in Iranian classical poetry? Or, do these exist at all in Iranian classical poems? If yes, which sorts of communication concepts and issues, especially regarding human communication, are mentioned? How are they dealt with? In what way are they presented?

No doubt it is beyond the scope of this paper to answer all of the above questions, but the aim is to provide sufficient explanations with respect to the issue of meaning in communications in Molavi's and Hafez's poems.

Before everything, we need to take a brief look at the two poets' biography and examine the form and content of their poems so as to become familiar with their unique styles and pave the way for a more efficient decoding of their works.

\section{A brief Background of Hafez's and Molavi's Poems}

One of the most famous Iranian poets, Jalal ad-Din Mohammad Balkhi, known as Molavi, was born the $7^{\text {th }}$ century A.H. (13 ${ }^{\text {th }}$ century A.D.) in the city of Balkh. His poems can be divided into two parts: the first one is an extensive poem called Masnavi-ye Ma'navi whose most reliable manuscripts include 25632 lines and which is composed of six books; the second one is a voluminous book with more than 100000 lines of verse which is known as Divan-e Shams-e Tabrizi (The Divan of Shams-e Tabrizz) since in the last line of many of its poems the name of Shams of Tabriz is mentioned and, indeed, the book is an appreciation of Shams, a mysterious character who was extraordinarily influential in Molavi's life.

Hafez, another universally acclaimed Persian poet, was born in the $8^{\text {th }}$ century A.H. (14th century A.D.) in Shiraz. His poems are mostly in form of ghazal and deal with the topic of love. His Divan, that includes nearly 500 ghazals, several qasidas, two masnavis, a few qit'as, and a number of rubais, has been so far printed 400 times in Persian as well as in different languages.

Molavi's tales in his Masnavi, that is one of the greatest mystical books of the world, as well as the themes dealt with by Hafez in his ghazals must have generally been in conformity with the Iran of those times, because, according to sociologists, the dominant subculture of each period must be traced in its literary and cultural productions. This can lead us to grasp the general conditions of the milieu wherein Molavi and Hafez lived.

By way of comparison, the two poets' works differ in that Hafez characteristically presents a huge variety of different meanings. However, we could think of them as two surrealist artists for their verse is imbued with meaning variety and plurality and they both composed poems by means of their unconsciousness. Additionally, on closer inspection, it can be claimed that Hafez was most probably influenced by Molavi. In fact, in the heart of Hafez's poems one might observe traces of Molavi. But if we consider the content closely in terms of intertextuality, we can find out that in many aspects Hafez cannot be said to be under the influence of Molavi's poems and, at any rate, it may not be a provable claim because they both inhabited the same cultural and mystical milieu. Therefore, it is not fair to assert that Hafez only made use of Molavi's poems, rather he used a great number of other sources as well. Another point is that Molavi's poems, unlike Hafez's, are dramatically various in terms of their audience. They move sometimes towards a general audience and sometimes towards a specific audience. It is a feature which was rarely heeded by the poetic tradition of his time.

Before embarking upon analyzing the concept of meaning in Hafez's and Molavi's poems, it is necessary to discuss western thinkers' ideas concerning the communication process. In the following, two well-known scholars, i.e. Dean Barnlund and David Berlo, will be mentioned who are famously accomplished in this regard.

\section{Meaning in Communications}

"Communications", writes Barlund, "as I conceive it, is a word that describes the process of creating a meaning." (1962:198) A more famous thinker, David Berlo, states that, "Communication does not involve transfer of meaning. Meanings are not transferrable. Only messages can be transferred and meanings do not lie in the messages, rather they lie in the minds of the users." Drawing upon an anecdote, Berlo states in a discussion under the title of "meaning of meaning" that "all of us have heard 
of the person who, when asked why a pig is called a pig, came up with the answer 'because it is dirty'. We make use of language to express and extract meanings. It is, indeed, the main function of language. Meaning is inherent to and inseparable from most definitions of language."

"Meanings do not exist in the message," further adds Berlo. "Meanings cannot be discovered. In fact, mere words will not yield a certain meaning; rather meanings lie in the human mind. Meanings elicit responses. They are private and exist in the human organism. Meanings are learned and counted as our properties. We learn them, add to or remove from them, but we cannot discover them. They are in us, not in the message. Normally we find individuals who possess meanings similar to those of us so that we could communicate with them. Only people with such similarities are able to communicate, otherwise communication is impossible. If meanings were in the message, it would imply that all people could communicate with each other irrespective of the language and code they used. If meanings were in the words, we would be able to break the words and bring out their meanings, but obviously we do not have such an ability. Some people attribute a specific meaning to a code, while others do not. Elements and structures of language lack any meaning in themselves; they are merely symbols and nothing more. Language acts as a signpost that helps us realise our intended meaning, think about it, as well as reorganise it... Meaning does not lie in the message. It is the task of the speaker to link the message to the audience's mind in a way that the message gains meaning in his mind according to the sender's intention." (1960: 173-176) In his Science of Communication (=Ertebat-shenasi), Mohseniyan-rad mentions three tales from Molavi's Masnavi in a chapter on meaning which represent well the gist of Berlo's ideas on meaning. Molavi has even succeeded to cover wider aspects through his poetically lucid and attractive language. The present author performed some case studies on Hafez's and Molavi's poems and extended the idea to what will be presented in the following.

\section{Molavi's Ideas on Meaning}

In Ghazal 462 of Divan-e Shams I was struck by a line which seemed to be a key line rather than an ordinary one. Here, after three lines about causality and about the fact that everything has a cause which is evidence of its existence and that very cause itself depends upon its result, Molavi addresses a question in the fourth line to the flowers in a garden as to who their evidence is while scent gains meaning only in the mind and colour in the eyes:

O! Roses and rose gardens, what is evidence of your being?

The scent in the brains, the colour in the eyes.

(Divan-e Shams, Ghazal 462)

The dictionary meaning of "evidence" is "an indication, a sign" — a sign that must prove the reality of the existence of flowers. "Garden" is a place where many flowers are grown and, in fact, Molavi is addressing both an individual flower and the multitude of flowers. He is referring to the fact that meaning does not exist in the message but it is created in the audience's mind. The message here is non-verbal and is sent through olfactory and visual channels to the audience, but it still needs be interpreted in the mind.

The second instance is a tale from Book I of Molavi's Masnavi, section 72. Animals in a jungle decide to submit themselves one by one to the lion as a prey. When it comes to the rabbit, he hesitates and justifies his delay by telling that there is a more powerful lion in the jungle who has captured the rabbit's friend. On hearing this, the lion infuriates and orders the rabbit to take him to the other lion's abode. The rabbit leads the lion to a well and points with fear to the inside of the well. When the lion faces the reflected picture of his and the rabbit, he interprets it as the rival lion and jumps down into the well.

Here, Molavi once again refers to the mental nature of meaning and states in the rest of the poem that in order to come up with a correct interpretation of message the receiver should receive it in clear and precise manner without any prejudice and devoid of any parasite. Thus, the receiver's obtained meaning can be conformed to the sender's intended meaning. As he states:

You're wearing lenses tinted funeral blue

And so this world is dark with grief to you-

(Masnavi, Book I, Section 72) 
Also in another poem Molavi mentions this point:

No bothering veil is hanging before your eyes;

Blessed be the limpidity of those eyes!

(Divan-e Shams, Ghazal 1099)

In explaining Molavi's ideas, we can draw upon Barnlund's statement that, "in the same way as we construct ourselves, we also construct others through communication." (2008: 55) Elsewhere he remarks that all through the communication process the receiver should well bear in mind his centrality and pivotal role. To this Farhangi also adds that, "our perception of a communication process is entirely dependent upon ourselves. In understanding and describing a communication process, every individual extremely relies upon himself and his mind and, as a participant in the process, whether as a sender or a receiver, he is confined to his view of his situation." (2008: 10)

In three other tales, Molavi discusses the issue of meaning. The first tale relates the story of an elephant which is brought into a city at night and everybody imagines its shape by touching one part of its body. The first person touches its trunk and conceives it as drain-pipe; the second feels the ear and imagines that it is a fan; the third one puts his hand on its leg and resembles it to a pillar; and the fourth one moves his hand on the back of the elephant and suggests that it is a flat thing. (Masnavi, Book III, Section 49) In this tale, a single phenomenon, i.e. the elephant, sends four different messages to four persons through tactile channel from which they receive various meanings.

In the second tale, a farmer ropes his cow in the barn at night and goes home. In the dark, a lion enters the barn, eats the cow, and lies there on the ground in place of the cow. The farmer comes at midnight to see his cow and instead touches the back of the lion. He conceives him as his cow, while the lion thinks to himself: If he knew me, he would not dare imagine me as a cow and stroke my back. When dawn falls he will see me and become frightened. (Masnavi, Book II, Section 14) Again, like in the previous story, a message is conveyed through tactile channel to the villager's mind which is interpreted improperly.

The third tale famously narrates the story of the four men - an Iranian, a Turk, an Arab, and a Roman - who receive a sum of money and decide to buy some grape. The Iranian suggests to buy "Angur" (the Persian term for grape); the Arab opposes and says, in his own idiom, that they should buy "Inab"; the Turk resists and insists on buying "Ozom"; and the Roman calls it "Estaphil". This causes a severe conflict to take place among them. (Masnavi, Book II, Section 112) Here, the same message is sent through aural channel to four individuals but different meanings are created in their minds. Apart from his delicate selection of characters from four prominent civilisations and the many nuances of this selection, Molavi again tells us in a highly artistic manner that some people assign certain meanings to some codes which others do not. Language is merely made of signs and does not contain any meaning in itself. It is much better for human beings to keep this fact in mind and prevent from harmful problems. As Mohseniyan-rad puts it, "words have a secret, and it is their being meaningless." (1990:91)

David Berlo has presented a model known as S-M-C-R. The letters stand respectively for the four main pillars of a communication process, namely, Source, Message, Channel, and Receiver. This model was developed in 1960 folowing the models by Aristotle, Lasswell (1948), Shannon and Weaver (1949), and Schramm's first (1949) and second (1954) models. Berlo's model is illustrated in Figure 1.

\begin{tabular}{|l|l|l|l|}
\hline Source & Message & Channel & Receiver \\
\hline $\begin{array}{l}\text { Communication } \\
\text { Skills }\end{array}$ & Content & Hearing & Communication \\
Attitude & Elements & Seeing & \\
Knowledge & Treatment & Touching & Attitude \\
Social System & Structure & Smelling & Knowledge \\
Culture & Code & Tasting & Social System \\
\hline
\end{tabular}

Figure 1. The main elements of communication process and their components in Berlo's $S-M-C-R$ model 
Molavi has made use of the four first channels in Berlo's list in the abovementioned tales and given variety to the stories by not adhering to a single channel. Besides creating variety, he also demonstrates that all senses are capable of conveying and receiving the message-and not simply a certain type of message but various messages - which can be interpreted in different ways in the mind. This would imply that meaning resides not in the message but in the mind.

\section{Hafez's Ideas on Meaning}

Unlike Molavi, Hafez does not utilise tales and anecdotes; therefore, he draws upon specific elements. As a result, before discussing Hafez's ideas on the issue of meaning, it is necessary to become acquainted with a major element of Hafez's poems, i.e. Saba Wind. Like many other poets, Hafez also shows naturalistic tendencies and makes use of a great many of natural elements. Sometimes he personifies objects and even attributes high and noble traits to them. As to wind, for instance, he has used 21 types in his poems: from wind of spring, autumn, Dey, Saba, to wind of distress, arrogance, loftiness, etc. Of course he names Saba Wind more than others and ascribes to it many characteristics. A search in Hafez' poems (Table 1) showed that the word "Saba" was mentioned 97 times and the word "Saba Wind" 23 times, which is indicative of the crucial importance of this wind in the poet's opinion. If looked at from the perspective communication studies, Saba Wind obviously indicates all of the components of a communication process:

\section{-Saba Wind plays the role of an informed source;}

Hafez consumed; and took not the perfume of the Beloved's tress:

Perchance, the guide of this fortune of his, the wind maketh.

(Ghazal,187)

I sacrifice my life in the trap of your hair

O morning breeze speak of the stranger in the night

(Ghazal,415)

\section{-It conveys information as the sender;}

With glad tidings, the breeze is the lapwing of Soleiman

That, from the rose-bed of Saba, tidings of joy brought.

(Ghazal,145)

Last night, news to me the messenger of the morning wind brought,

Saying: "To shortness, its face, the day of labor and of grief hath brought."

(Ghazal,147)

\section{-It acts as a channel for transferring information;}

Along with the wind, send from Thy cheek a handful of roses:

It may be that I may perceive a perfume from the dust of the rose garden of Thin.

(Ghazal,12)

O Breeze! If thy path should chance by the Land of the Friend.

Bring a fragrant waft of air from the be perfumed tress of the Friend.

(Ghazal,61)

At morning time, a perfume from the Beloved's tress, the breeze brought:

Into action, our heart distraught for Thee brought.

(Ghazal,146)

\section{-Sometimes it plays the role of a harbinger;}

If from Thee, the footman of the east wind will learn work possible: 
For movement, swifter than this, the wind made not.

(Ghazal,138)

It is the receiver of the message; it creates the meaning in the receiver's mind; and many other roles can be enumerated for Saba Wind, each of which is evinced by a remarkable number of instances. Of course, one or two verse lines were mentioned as instance for each of the cases above except for Saba's role as a channel since exactly this is the role we intend to deal with here.

As well as transmitting messages and information, Saba also performs an interesting act and it is the carrying of the beloved's scent to the poet. This causes the meaning, which is the remembrance of the beloved, to crystallise in the poet's mind. In fact, Berlo's theory that meaning does not lie in the message but in the audience's mind is most accurately exemplified in the following line:

It should not be neglected that Hafez makes use of Saba Wind to convey messages through olfactory channel and make necessary associations in the poet's mind to create the intended meaning.

Given the channels used by Hafez and Molavi we can draw, according to Berlo's model, a diagram and tables as following:

Figure 2: The channels used by Hafez and Molavi in their poems about meaning according to Berlo's S-M-C-R model

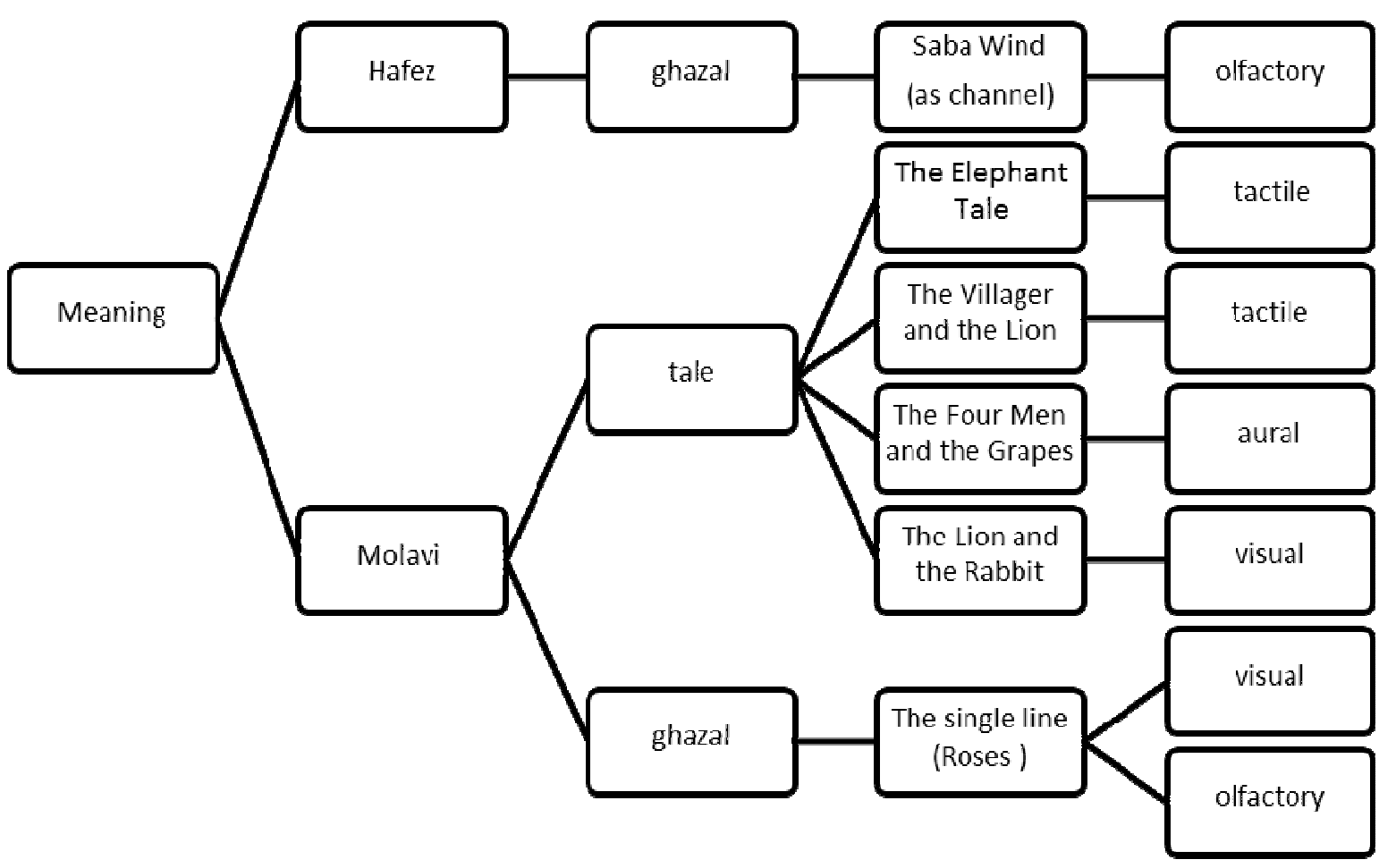

Table 1. Frequency of different communicative forms of Saba in the sample

\begin{tabular}{|l|l|l|}
\hline Phrase & Frequency & Percent \\
\hline Saba Wind & 23 & 54.76 \\
\hline Saba Breeze & 2 & 4.76 \\
\hline Harbinger of Saba & 3 & 7.14 \\
\hline O! Saba & 12 & 28.57 \\
\hline O! Harbinger of Saba & 1 & 2.38 \\
\hline O! Saba Wind & 1 & 2.38 \\
\hline Total Number & 42 & 100 \\
\hline
\end{tabular}


Table 2. The frequency of the channels used by Hafez and Molavi in their poems about meaning according to Berlo's $S-M-C-R$ model

\begin{tabular}{|l|l|l|}
\hline Channel & Frequency & Percent \\
\hline tactile & 2 & 28.57 \\
\hline aural & 1 & 14.28 \\
\hline visual & 2 & 28.57 \\
\hline olfactory & 2 & 28.57 \\
\hline gustatory & 0 & 0 \\
\hline Total & 7 & 100 \\
\hline
\end{tabular}

\section{Conclusion}

Discussion of meaning in the communication process is not something unique to our age or confined simply to a number of western thinkers. It is a long-standing issue that has attracted the attention of mankind over centuries — a fact which was proved in the analysis performed in this paper on Molavi's and Hafez's poems, two succeeding Iranian poets.

Molavi addresses the issue mostly by means of tales and narration involving both human and animal characters. He illustrates the communication process as artistically and, at the same time, simply as possible and points out to the lack of meaning in message. These tales are greatly various and revolve mainly around Berlo's ideas on meaning while also being imbued with humane concepts. Of course we can interpret and decode Molavi's intended ideas from other viewpoints, which is indicative of his ability of expressing subtle and multivalent ideas, but, as mentioned earlier, this aspect is so remarkable in his poems that is highly likely to be the one intended by Molavi himself.

On the other hand, Hafez performs a similar task with his love poems. Making no use of narration, he employs natural elements, and here especially Saba Wind, as skillfully as possible. Saba takes numerous communicative roles in Hafez: as an informed source; as a sender that informs; as message-giver; as a channel that transmits information; sometimes as a harbinger; etc. It crystallises the meaning in the mind of the receiver, i.e. the poet. The lover and the beloved, in Hafez's poems, use Saba Wind as a channel to exchange meaning and, thus, Saba makes a meaning each time it conveys the scent of the beloved to her lover.

\section{Refrences}

Barnlund, D. C. (2008) 'A transactional model of communication'. In. C. D. Mortensen (ed.), Communication Theory, 2nd ed., New Jersey: Transaction Publishers, pp 47-57.

Berlo, D. (1960) The Process of Communication. New York: Rinehart and Winston.

Eslami-Nodushan, M. A. (1381) Chahar Sokhan-guy-e Vejdan-e Iran [Four Speakers of Iranian Conscience], Tehran: Ghatreh.

Farhangi, A. A. (1387) Ertebat-shenasi [The Science of Communication], vol. 1, Tehran: Rasa Institute of Cultural Services

Foruzan-far, B. (1384) Zendegi-ye Molana Jalal-o-din Mohammad-e Balkhi Mashhur be Molavi [The Life of Molana Jalal ud-Din Muhammad Balkhi known as Molavi], Tehran: Zavar

Hafez, Sh. M. (1368) Divân-e Hafez, edited by M. Ghazvini and Ghasem Ghani, Tehran: Asâtir

Hagh-shenas, A. M. (1370) Majmu'eh Maghalat-e Adabi Zaban-shenakhti [Linguistic-Literary Essays], Tehran: Niloofar.

Hagh-shenas, A. M. (1382) Zaban va Adab-e Farsi dar Gozar-gah-e Sonnat va Moderniteh Persian Language and Literature in the Passage from Tradition to Modernity], Tehran: Niloofar.

Khorram-shahi, B. (1372) Hafez-nameh [The Book of Hafez], Tehran: Elmi-Farhangi.

Khorram-shahi, B. (1389) Zehn va Zaban-e Hafez [Hafez's mind and idiom], Tehran: Nahid.

McQuail, D. (1388). Daramadi bar Nazariyeh-ye Ertebatat-e Ejtema’i [Mass Communication Theory: An Introduction], translated by Parviz Ejlali. Tehran: The Office of Development and Studies of Media.

Mohseniyan-rad, M. (1387a) Ertebat-shenasi [The Science of Communication], Tehran: Sorush.

Mohseniyan-rad, M. (1387b) Rishe-ha-ye Farhang-ye Ertebat dar Iran [Cultural Roots of Communication in Iran], Tehran: Chapar.

Molavi, J. M. (1381) Masnavi-ye Ma'navi [Manavi Ma'navi], edited by R. Nicholson and M. H. Foruzan-far Tehran: Maleki.

Mo'tamed-nezhad, K. (1386) Vasayel-e Ertebat-e Jam’i dar Iran [Means of Mass Communication in Iran], Tehran: Tehran University Press.

Nasiri-Jami, H. (1388). 'Razmandi-ye Bad-e Saba dar She’r-e Hafez’ [Mysteriousness of Saba Wind in Hafez' Poetry], 
Faslnameh-ye She'r va Adab (7).

Renard, J. (2005) A Historical dictionary of Sufism. Plymouth: Rowman \& Littlefield.

Severin, W. J. and James Tankard (1386) Nazariye-ha-ye Ertebatat [Communication Theories: Origins, Methods, and Uses in the Mass Media], translated by Alireza Dehghan, Tehran: Tehran University Press.

Zamani, K. (1388) Sharh-e Masnavi-ye Ma'navi [Annotations on Masnavi Ma'navi], Tehran: Ettela'at. 